\title{
That Used to Be Us: Through the Eyes of the Aviation Industry
}

\author{
Kelly Whealan George \\ Embry-Riddle Aeronautical University
}

\begin{abstract}
The U.S. economic success was rooted in an industrial policy which had five pillars of a prosperity formula that served as a catalyst for development and growth: 1) public/private cooperation on education, 2) immigration policy, 3) infrastructure, 4) risk/capital management, and 5) government-funded scientific research. In this paper, the development and growth of the aviation industry is viewed in the framework of such a prosperity formula in order to face the four areas that the entire economy will need to face in the current market in order to be competitive in the global market in the $21^{\text {st }}$ century. Since the aerospace and aviation industry is an integral part of the US economy, it stands that those elements will also challenge the aviation industry's future. Considering the economic history of the industry and the prosperity formula, the industry has opportunities for not only normal growth but potentially can be used as a catalyst for industry health, significance and renewal in the future as well as the indirect aviationrelated industries. It is clear that further research and thought are needed to provide pathways to meet the four economic challenges in the aviation sector identified in this paper. It is hoped that this paper will serve as a foundation for that research.
\end{abstract}

\section{Introduction}

Thomas Friedman is an award winning American Pulitzer Prize foreign policy journalist who spent a large portion of his career since 2000 writing about globalization and economic growth. Friedman's 2011 book with co-author Michael Mandelbaum, That Used To Be Us, presents a five-part formula for success derived from U.S. economic history and advocates this formula as a vehicle for future economic growth against current challenges (Friedman \& Mandelbaum, 2011).

According to Friedman and Mandelbaum (2011), U.S. economic success was rooted in an industrial policy which had five pillars of a prosperity formula that served as a catalyst for development and growth: 1) public/private cooperation on education, 2) immigration policy, 3) infrastructure, 4) risk/capital management, and 5) governmentfunded scientific research. The authors argue that collectively, the five pillars are at a cross roads and current trends do not bode well for U.S.'s economic future. Worse, no one pillar had reached a point of criticality that would spur immediate action and reversal (Issacson, 2011).

In this paper, the development and growth of the aviation industry is viewed in the framework of Friedman and Mandelbaum's (2011) prosperity formula and also presents 
four areas that the entire economy, and certainly the aviation industry will need to face in the current market in order to be competitive in the global market in the $21^{\text {st }}$ century.

\section{Quantifying the Aerospace and Aviation Industry}

Customarily the entire aviation industry is divided into two major subcategories, aerospace and aviation. The aerospace industry is defined as the manufacture of general, commercial, and military aircraft, and related products such as spacecraft and missiles. Aviation is a shorthanded way of referring to air transportation that includes the operation of scheduled commercial airlines, freight operations, and nonscheduled passenger and freight air transportation (Aerospace Industries Association of America, 2011; Bureau of Economic Analysis, 2011).

It is safe to say that the aviation industry did not have a large place in the U.S. economy before the Wright Brothers flew at Kitty Hawk in 1903. The industry was not really an industry at all but a collection of enthusiasts and scientists. The Bureau of Economic Analysis (BEA) accounts of economic output began breaking out data by industry in 1947. In 1947, aerospace manufacturing was lumped into the aggregate manufacturing accounts and air transportation did not even exist as a subaccount. The distinctions and importance of separate economic data between aerospace and aviation industries probably began during the industrial military buildup from the Cold War, which also coincided with a maturing air transportation industry. Air transportation output was specifically broken out from the transportation accounts in the BEA for the first time in 1977. In 1977, aerospace and aviation accounted for only $1.5 \%$ of the US economy. By 2010, the US aerospace and aviation industry was $0.8 \%$ of the total U.S. employment and contains one of the last remaining strong manufacturing sectors of the US economy; however, recent trends in this industry show that the industry is declining (Aerospace Industries Association of America, 2011; United States Department of the Labor, 2011).

\section{Evidence of the Five Pillars in the Industry’s Development}

Public/Private Cooperation on Education. When World War I ended, the future aviation industry was highly uncertain as many government contracts were cancelled and companies liquidated to leave the industry operating at only $10 \%$ of its wartime peak. The industry needed to refocus away from a military product to develop a commercial product demanded in the ensuing peacetime. The Manufacturers Aircraft Association, headed by Samuel S. Bradley, embarked on the 1919 version of the modern day "Got Milk" campaign by publishing the Aircraft Year Book, in order to educate the public and promote flying.

By the time Mingos (1930) wrote a historical commentary on the birth of the aviation industry, he noted that a great industry had grown from aviation enthusiasts. Since 
industry output breakdown was not available, the only way to estimate what portion of the economy was devoted to aviation production was by the number of workers employed in the industry. At the end of World War I, 175,000 workers or $0.4 \%$ of the U.S. labor force was directly employed by the aviation industry (Mingos, 1930; United States Department of the Labor, 2011). Aviation had gone from a cottage industry to an identifiable industry of 24 aircraft companies representing a \$23 million capital investment that was intertwined with 75 different industries within 21 months during World War I. The initial push for the organization of the industry, technological cooperation, patent royalty sharing agreement, and product demand came via the US Government as a direct involvement in World War I, but was buoyed by the private industrial association's education and promotional campaign of aviation.

Formal flying schools were also established in the 1920s, but it was the experience of World War II that drastically expanded not only the military pilot training programs but also the private schools that were contracted by the government. This educational push strengthened the advancement and development of the industry. When World War II was over, military pilots came home and helped fuel the general aviation expansion to five times what it was prior to the war (McCurry, 2000).

Numerous isolated aviation educational experiences began at the University level before the Wright Brother's first flight. The early beginnings of formal aerospace education programs began before 1920 with the first master's degree awarded at Massachusetts Institute of Technology (MIT) in aeronautical engineering and the first Department of Aeronautics was established at the University of Michigan. Others soon followed. Beginning in 1925, the Guggenheim Foundation, a private institution, also contributed much to the development of early programs in aeronautical engineering. In the 1940s, the number of aerospace engineering programs rapidly expanded as a result of World War II and these programs were substantially subsidized by the government. (American Institute of Aeronautics and Astronautics, 2009; McCormick, 2004).

Many argue that the achievement of manned flight would have occurred sooner with better communication between the practitioners' experiments and the theoreticians (Kiernan, 2011b; McCormick, 2004) . It is difficult to determine which came first, education or industry. Air transportation had just begun to take-off as more respected aerospace educational programs became established. This formalized transfer of knowledge, research results and educational discovery with industry began to take place with the establishment of formal aeronautical educational programs and helped fuel the development of the industry. As more aerospace technology was created, a myriad of aviation uses became available which were not considered before. But just as important, as necessity presented itself, academic researchers rose to the occasion to solve the aeronautical technological challenges that were discovered by practice.

Current aerospace and aviation educational programs are available within academic institutions, military institutions, and institutions that evolved from proprietary schools. 
The proprietary schools are a mix of public and private providers and given the nature of government supported financial programs, many times they overlap. The discipline of engineering (all fields) conferred $7.7 \%$ of the total bachelor's and $8.5 \%$ of all master's degrees awarded in the U.S. in 2009 (National Center for Education Statistics, 2010). Aeronautical engineering graduates grew $44 \%$ in 2009 and the field remains one of the top paying industries for master's degree graduates (National Center for Education Statistics, 2010).

Immigration Policy. It is difficult to trace the specific contribution of the nation's immigration policy to the development of the aviation industry. The United States is from origin, an immigrant country and had a relatively open-door policy until the surge of immigrants after World War I. At that time, the numbers of immigrants allowed into the country was managed by the government (United States, Senate Congressional Budget Office, 2006). One would expect the aviation industry to exhibit a stamp of notable immigrants. Fry (2003) claims the Scots have placed their mark on the aviation and aerospace industry. Notable aviation pioneers with Scottish decent including Samuel Pierpont Langley; Allan and Malcolm Loughead (founders of Lockheed Inc.); Donald Wills Douglas, Sr. (first commercial airplane in 1921 and others later); James Smith McDonnell (founder of McDonnell, manufacturer of military aircraft); and Dr. John Watret (Chief Academic Officer and Executive Vice President of Embry Riddle Aeronautical University) (Embry Riddle Aeronautical University, 2011; Fry, 2003).

The aerospace industry also benefitted from a national security immigration policy after World War II. The War Department, circumventing State Department regulations, brought in numerous German scientists while the U.S. was still at war with Japan. After the War, the State Department allowed limited immigration of critical scientists who met certain criteria. Initially, immigrant scientists could not be members of the Nazi party, but later it was decided that this criterion was too restrictive. Many felt the only reparations the U.S. was likely to receive were the intellectual reparations of Germany's "rare minds". Additionally, it soon became a mixture of wanting the knowledge and wanting to deny the knowledge to the Soviets as the U.S. entered the Cold War and the aerospace industry experienced great expansion. This intellectual immigration had a huge impact on space and rocketry. The German team dominated rocketry until they basically died or retired. A large percentage of the space scientists who were German fanned out into indirect aerospace fields such as ceramics, aerodynamics, propulsion, etc. (Keinon, 1990; Kiernan, 2011a).

Infrastructure. Clement Keys, the chief executive officer of Curtiss Aeroplane and Motor Company, remarked that $10 \%$ of aviation was actually in the air while $90 \%$ of it was on the ground, as the logistical dance between the air and ground facility is what allowed the industry to be developed and maintain an ongoing business (Komons, 1989). Barnstorming had not left the public with the impression that flying was a safe form of transportation. Unless reversed, this attitude would not allow the industry to develop. 
The airmail system, arguably the beginning of the air transportation sector, developed through a loose collection of air fields that aided night flying by the lighting of bonfires. It was only in 1920 that the Post Office Department ordered installations of radios at each field that was not already provided a radio by the Navy Department stations. The radio stations and then beacons that replaced bonfires became the early pilot guidance system for air transportation, allowing for the expansion of the system into the night and adverse weather conditions. In 1927, the transcontinental system of the airway and radio service, 43 pilots and 600 ground and office employees were transferred out of the Post Office Department to the Department of Commerce and private companies took over these operations. The establishment of the infrastructure and the air mail experience gave stimulus for the establishment of commercial aviation in the U.S. (Lipsner \& Hilts, 1951). Clement Keys comment was certainly as pertinent in the 1920 s as it is today.

Throughout the 1930s, aviation experienced technological advances in aircraft equipment and public infrastructure that boosted airlines into a vast system of national transportation services that yielded profits for private operators. As the nascent air industry was beginning to grow, the Air Commerce Act of 1926 and the establishment of the Civil Aviation Authority (CAA) in 1938 was created to regulate routes, mergers and airfares becoming the cornerstone of the nation's aviation policy fostering future development of the air transportation industry (Komons, 1989).

During the 1940 - 1960's, aviation diverged into military production and commercial production. Government involvement and funding incited the growth and development of aviation and its services for military purposes while commercial aviation adopted various technologies for their own domestic use. The military sought to develop equipment to not only develop the theory of superior airpower as a strategy on a battlefield, but also the development of long range cargo transport aircraft. Not only was equipment developed and produced, the related indirect aviation services, equipment and educational pipelines experienced development and expansion. (Connolly, 2000). General aviation or private aviation, along with the support facilities and training industry, also began to emerge as a separate industry in the 1940s, following the war, and throughout the 1970s (McCurry, 2000).

By 1958, the government passed the Federal Aviation Act which ultimately led to the establishment of the Federal Aviation Authority (FAA) and the Department of Transportation (DOT). It was clear that the government organization, administration, and regulation of the public domain of airspace was needed for the continuing expansion of the non-military sector of the aviation industry and the public's continued integration of aviation into their daily lives. This step was very similar to the initial regulations the government enacted with the Air Commerce Act of 1926 as a way to promote aviation and aviation safety (Brady, 2000b; Saini, 2011). The standardization of aviation facility requirements was a must to instill a sense of stability and safety in the minds of consumers. 
By the 1970s, military aviation was a completely separate industry from commercial aviation even though some manufacturing providers operated in both sectors. Whereas before, aviation technology was typically advanced from a military need in origination, and it later had spillover effects into the private sector. However, during the 1960s and 70 s, commercial aviation began to expand independent of the military aviation complex. By the end of the 1970s, commercial aviation could be thought of as a separate system (Leher, 2000).

By 1978, the airline industry was no longer an infant industry needing regulation for protection in order to continue to grow and become stable. Starting in 1978 and ending in 1984, the airline industry was deregulated. After deregulation, economic indicators for the airlines improved in aggregate. Since deregulation, the airline industry has experienced expanded routes, mergers, entrants, recessions, oil price shocks and then restructurings. The cost of travel dropped almost 50\% for the consumer and the average cost of production due to increased carriage has decreased by $28 \%$. Today, consumers have more money to spend on more travel or other goods and the airlines are providing more of their services (May, 2008; Wilson, 2008).

The gradual removal of operating and economic controls in the air transportation industry spurred the rapid expansion of services through the greater development of the hub and spoke system of the airlines. The prior economic structure imposed on the market had been an economic deadweight loss or a drag to the growth of the industry. General aviation also experienced significant growth in demand and was faced with increased regulation and market pressures from the expansion of the commercial airlines into their customer base (McCurry, 2000).

The growth and success of aviation's movement of goods and services through its air transportation system is largely due to the expansion of its system of airfields and then airports in the nation. In the 1920s, the military had a hand in selecting the sites. Geographic location, topography, present structures and land prices were considered when selecting sites for airfields. In the 1930s, many areas used funds from the Works Progress Administration (WPA) to improve aviation facilities. In 1940 the Civil Aeronautics Administration (CAA) duties included air traffic control, certifying airman and aircraft, safety enforcement and airway development. Financial aid aimed exclusively at the continued development of the nation's airports was established by President Truman in 1946. The Federal Aviation Act of 1958 created the Federal Aviation Agency that later evolved into the Federation Aviation Administration (FAA) that continued to provide support to the nation's airway infrastructure required for the development of the air transportation industry and responsibility for air traffic control services. The invention of the jet engine, modern airport construction with extended runways, and expanded passenger facilities exploded in the 1960s. The Airport and Airway Development Act of 1970 established the Aviation Trust Fund to provide revenues for airport and airway modernization (The beginning of an adventure, 2003). 
Airport ownership is a complex relationship. Airports are owned and invested in by local governments and the private sector which can make it difficult to determine whose needs are primary, local, national, or system-wide issues. According to the American Society of Civil Engineers, in 2009, the National Planned Integrated Airport System (NPIAS) was comprised of 3,356 existing publicly owned, public-use airports in the U. S., with an additional 55 proposed. There are also 522 commercial service airports, and of these, 383 had more than 10,000 annual enplanements and were classified as primary airports. (American Society of Civil Engineers, 2010).

From the early 1900s to World War II, the aviation industry was in its knowledge discovery period, registering many historical firsts and developing innovation. This is not meant to minimize the continued innovation in the aviation industry that still continues to this day, but the early innovations laid the foundation for the development of the industry. From the mid-1920s up through the 1960s a systems-thinking perspective began to develop around the airline industry. A series of government acts created a more structured environment and the industry began to separate into three distinct industries with some crossover between military, commercial, and general aviation (Ferreira, 2001). The aviation industry matured into a major system that included infrastructure in the air as well as the ground.

Risk/Capital Management. Risk and capital management is essentially the legal and financial framework of the nation that supports a functioning economy. Risk and capital management within the U.S. is regulated to guard against financial abuse, the protection of intellectual property, and to provide an amenable business climate across all industries (American Institute for Aeronautics and Astronautics, 2005). With a friendly capitalistic business climate that is relatively politically-interference free, entrepreneurs risk their energy and talent in the pursuit of making themselves richer, as well as the development of the U.S.'s aviation industry along the way. The government creates the foundations for risk taking and innovation that the private sector fulfills and the U.S. is a model for attracting capitalists looking to succeed.

As of 1917, the aviation industry was a formal association comprised of 12 manufacturing companies operating under a cross-licensing agreement that allowed its members use of all the aviation patents and was charged by the U.S. government with manufacturing 25,000 planes for the war effort. The cross-licensing agreement remained in place until the viable expansion of the commercial side of the industry developed in the next decade and allowed all in the industry to work on and take advantage of technological advances in the industry (Mingos, 1930; Whealan George, 2011). This is one example of the legal financial structure provided in the U.S. that acted as incentive for entrepreneurs to strategically invest capital in various businesses with the intent to profit.

The expansion of the air mail program as the first practical commercial application of aircraft with passenger carriage followed soon. There were some private companies such 
as the St. Petersburg-Tampa Airboat line or Chalk's International Airlines operating without government support, but the overall push for the organization of these services was government originated with private partners. Walter Brown came to office as the Assistant Secretary of Commerce under President Hoover with an intention to develop the fledgling air transportation system into a fully functioning industry (Brady, 2000b; Komons, 1989). Brown's research led to a number of conclusions that did not bode well for an air transportation system on the cusp of bursting forth with growth and maturity under their own devices. Transportation companies that sought to carry passengers instead of mail experienced, at a minimum, an 83\% drop in revenue given the market prices for tickets; therefore, there was no business market incentive to expand into the passenger line of business (Arnold, 2011; Brady, 2000b). The air transportation industry was not a profitable industry and did not incentivize investing and using the most technologically advanced equipment available (Fredrick, 1961). Brown concluded that the government needed to provide structure and subsidies within the system as well as incentives and risk mitigation to develop his and Hoover's vision of a passenger carrying air transportation system from within the existing 44 small airlines in operation in 1928 (Freeman, 2003).

Between 1927 and 1934, the air mail and passenger carriage system was organized into a highly regulated competitive industry. When Brown left office, the country was in the midst of a severe depression but aviation was an industry that not only showed promise but was expanding and air mail costs had decreased by 51\%. From 1929 to 1934, airline employment jumped $250 \%$ at a time when the aggregate unemployment rate in the U.S. went from 3\% to 24\% (Brady, 2002). While Brown's means eventually were deemed illegal and the government contracts were re-competed, it was the organizational structure that was set up under Brown that yielded the initial regulated marketplace for the air transportation industry.

During the time frame of the late 1920s to early 1930s, another major characteristic on the supply side holding back the expansion of the industry was lack of coordinated aviation infrastructure and foreigners dumping their cheap, lower quality products into the market. The government interceded with default regulations that stipulated the quality of the aircraft imported into the U.S. that insulated the domestic producers from producing a product that would be a financial loser.

At the same time, the Aeronautical Chamber of Commerce was organized with a mission to advance an integrated plan to develop all aspects in trade of the commercial aviation industry. The demand for commercial aviation services drove the regulatory organization and the building of the supporting infrastructure described in the previous section. With the demand, regulations and facilities plans in place for a comprehensive national industrial policy, capital financing followed. But one factor should be reiterated, it was through the work of the chamber of commerce - the private sector - combined with the regulatory environment that led to the proper combination for the development of the national industrial policy that drew capitalists to the development of the modern 
aviation industry (Mingos, 1930). The cornerstone of the modern aviation industry was set with the passing of the national air law in 1926, placing commercial aviation under the responsibility of the Department of Commerce and giving commercial aviation a place at the table within the Executive branch of the government. As Dr. John Johnson, president of Embry Riddle Aeronautical University claimed, "If you want to shape the agenda, make sure you have a seat at the table” (Johnson, 2010). Aviation had just received a seat at the table.

Fast forward to deregulation of the industry in 1978 when Congress agreed that the industry no longer needed protection. Airlines had to respond to a more businesslike environment subject to the prevailing economic conditions. They were also free to innovate as a core characteristic of a business in a competitive environment. Competition in any industry is beneficial, not destructive, because it yields efficiency and lower prices for consumers, as well as industry innovation. Competition is only destructive if the airline in question is the one that refuses to innovate or become more efficient. In fact, competition pushed airlines to innovative efficiencies in their reaction to macroeconomic shocks, which in turn benefitted the consumers through lower prices and more traveling options (Tom, 2009). Innovations that may not have been realized under a regulated system included hedging fuel costs (Southwest Airlines), more efficient equipment (Boeing 787), increasing capacity utilization by shrinking fleet structures, and scrutinizing the weight of airplanes to maximize fuel consumption (American Airlines). By allowing the market to operate freely under the existing legal structure, especially when faced with low margins, the industry is induced to be creative to find new sources of revenue and new ways to operate efficiently.

Government-funded Scientific Research. In the period before the Wright Brother's successful flight in 1903, aviation could only be deemed as an emerging science, but it was not without government-funded research. Langley was coaxed out of retirement into what is now referred to as the acquisition world by the US government with the Great Aerodrome project. Langley, with an award of $\$ 50,000$, was likely the first defense contractor; or, as referred to in D.C., a beltway bandit, pursuing the development of an airplane (Brady, 2000a; Shulman, 2003; United States Senate, 1907). This \$50,000 contract, awarded in 1898, was valued at $\$ 1,180,000$ in 2010 dollars and was arguably the earliest version of the development of an airplane that was possibly capable of launching off an aircraft carrier (U.S. Department of Commerce, 2011). Given the current price tag of the newest carrier aircraft, the $\$ 200$ million F-35, this investment by the Department of Defense (DoD) was a bargain (Tierney, 2011). Langley believed his work chasing mechanical flight should not be the property of a single benefactor and he ignored private funding options for the continuation of the discovery of flight (U.S. Department of Commerce, 2011).

From 1903 to 1917, interest in the continued development of the airplane was spurred by government contracts, competitions for announced prizes, and air meets. The first government contract for an airplane was between the U.S. Army and the Wright Brothers 
in 1907 , for a cost of $\$ 25,000$ per plane, or $\$ 577,374$ in 2010 dollars (Brady \& Crehan, 2000; Bureau of Economic Analysis, 2011). At this point in time, it is safe to say that the foremost interest in developing the aviation industry would be for military uses (World rivalry in flying machines and motor boats, 1908). These competitions also highlighted the indirect industry that would need to be developed along with the direct aviation manufacturing and transportation sectors of the economy.

From 1915 to 1958, the National Advisory Committee for Aeronautics (NACA) was the predominant government body supporting aviation research and development. NACA also published its technical documents and was recognized as an authority on aeronautical engineering research. Research from World War II military aviation spun off into private sector advancements. Foremost in the NACA and later National Aeronautics and Space Administration (NASA) roles in research was the focus on broad-based research applications of aviation that could then be taken by the private sector and leveraged to be further advanced. Applications of research were not the focus or concern of the scientists as that was to be determined later by the private market by the difference of supply and demand. This foundation served across a wide spectrum for research and for the transfer of technical information and expertise (Committee on Science, Engineering, and Public Policy (U.S.) Panel on the Government Role in Civilian Technology, 1992).

The Defense Advanced Research Projects Agency (DARPA), established in 1958, is just one example of a government sponsored agency supporting research in development of high-risk, advanced technologies that have applications to the military sector and commercial industries. DARPA acts as a talent agent for the government, outsourcing research to private sector, academia, and military branches for the collective benefit to the U.S. Since 1989, DARPA has also been tasked with the responsibility to advise and manage the transfer of the results of research with commercial applications to industry (Committee on Science, Engineering, and Public Policy (U.S.) Panel on the Government Role in Civilian Technology, 1992).

The American Institute of Aeronautics and Astronautics reported in 2005 that the benefits of government sponsored aeronautics research can be witnessed from the absolute level of the industry within the nation's GDP, but also the future competitiveness of the entire nation's workforce and the nation's ability to provide the public good, the air transportation system (American Institute for Aeronautics and Astronautics, 2005). The AIAA reported that government funded research was partly responsible for the trade surplus of $\$ 31$ billion dollars in 2005 while most other sectors showed deficits. Government funded or partnered research has been vitally important to the development of the aviation industry in and of itself, and in its importance to the nation's economy. 


\section{Looking to the Future}

Friedman and Mandelbaum (2011) presented four major economic challenges that the future U.S. economy depends upon: 1) globalization, 2) revolution of information technology, 3) nation's chronic deficits, and 4) the pattern of the nation's energy consumption. They argue that to meet those challenges, the nation needs to work through their five pillars of the prosperity formula that worked in history to develop our competitive economy. Those challenges were constructed with a view of the macroeconomic economy. Since the aerospace and aviation industry is an integral part of the US economy, it stands that those elements will also challenge the industry's future. Considering the economic history of the industry and the prosperity formula, the industry has opportunities for not only normal growth but potentially can be used as a catalyst for industry health, significance and renewal in the future as well as the indirect aviationrelated industries.

Using the lens of the prosperity formula: 1) public/private cooperation on education, 2) immigration policy, 3) infrastructure, 4) risk/capital management, and 5) governmentfunded scientific research: one can trace how the aviation industry grew to be such an important sector of the U.S. economy. It follows that this formula can be harnessed by the government and the private sector to marshal in future prosperity for the industry. Through the five pillars of Friedman and Mandelbaum's (2011) prosperity formula, the aviation industry can meet the current market challenge in order to be competitive in the global market in the $21^{\text {st }}$ century. It is clear that further research and thought are needed to provide pathways to meet Friedman and Mandelbaum's (2011) identified four economic challenges in the aviation sector identified in this paper. It is hoped that this paper will serve as a foundation for that research. 


\section{References}

Aerospace Industries Association of America. (2011). Aerospace industry report 2011. Arlington, VA: Author.

American Institute for Aeronautics and Astronautics. (2005). Revitalizing United States aeronautics research and development funding. Washington, D.C.: Author.

American Institute of Aeronautics and Astronautics. (2009). Who was Daniel Guggenheim? Reston, VA: Author.

American Society of Civil Engineers. (2010). Report card for aviation infrastructure. Retrieved, from http://www.infrastructurereportcard.org/fact-sheet/aviation.

Arnold, R. (2011). Economics (10th ed.). Mason, OH: South-Western Cengage Learning.

Brady, T. (2000a). Developments before the Wright brothers. In T. Brady (Ed.), The American aviation experience: A history (pp.13-47). Carbondale, IL: Southern Illinois University Press.

Brady, T. (2000b). U.S. airlines from 1930 to World War II. In T. Brady (Ed.), The American aviation experience: A history (pp. 171-184). Carbondale, IL: Southern Illinois University Press.

Brady, T. (2002). The Orteig prize. Journal of Aviation/Aerospace Education \& Research, 12(1), 45-49.

Brady, T. \& Crehan, J. E. (2000). Development between the wars. In T. Brady (Ed.), The American aviation experience: A history. (pp. 151-170). Carbondale, IL: Southern Illinois University Press.

Bureau of Economic Analysis. (2011). Industry economic accounts information guide. Retrieved from http://www.bea.gov/industry/iedguide.htm\#bioa.

Committee on Science, Engineering, and Public Policy (U.S.) Panel on the Government Role in Civilian Technology. (1992). The government role in civilian technology: Building a new alliance. Washington, D.C.: National Academy Press.

Connolly, T. (2000). World War II. In T. Brady (Ed.), The American aviation experience: A history. (pp. 185-217). Carbondale, IL: Southern Illinois University Press.

Embry Riddle Aeronautical University. (2011). Administration. Retrieved from http://www.erau.edu/administration/senior-leadership/watret.html. 
Ferreira, P. (2001). Systems in transportation: The case of the airline industry. Unpublished manuscript. Retrieved from www.web.mit.edu/esd.83/www/notebook/ESD83-Airlines.doc.

Fredrick, J. H. (1961). Commercial air transportation. Homewood, IL: Richard D. Irwin.

Freeman, R. (2003). Walter Folger Brown: The postmaster general who built the U.S. airline industry. Retrieved from http://www.centennialofflight.gov/essay/ Commercial_Aviation/Brown/Tran3.htm

Friedman, T. L., \& Mandelbaum, M. (2011). That used to be us : How America fell behind in the world it invented and how we can come back. New York City, NY: Farrar, Straus and Giroux.

Fry, M. (2003). How the Scots made America. New York City, NY: St. Martin's Press.

Issacson, W. (2011). An interview with Tom Friedman. [Interview transcript]. Retrieved from http://www.aifestival.org/session/new-tom-friedman

Johnson, J. (2010, January). President's remarks. Presentation to Doctoral Students at the DAV 701 residency of Embry Riddle Aeronautical University, Daytona Beach, FL.

Keinon, H. (1990), Rocket man ascends to Zion. Jerusalem Post, p. 10.

Kiernan, K. (2011a). Project Paperclip and its Repercussions: Exploring American Recruitment of German Aerospace Scientists Following World War II. Unpublished manuscript. Embry Riddle Aeronautical University, Daytona Beach, FL.

Kiernan, K. (2011b). Re: On the other hand. [Discussion board post].

Komons, N. A., \& United States. (1989). Bonfires to beacons : Federal civil aviation policy under the Air Commerce Act, 1926-1938. Washington, D.C.: Smithsonian Institution Press.

Leher, H. R. (2000). U.S. air carriers after World War II. In T. Brady (Ed.), The American aviation experience: A history. (pp. 218-240). Carbondale, IL: Southern Illinois University Press.

Lipsner, B. B., \& Hilts, L. (1951). The airmail, jennies to jets. Chicago, IL: Wilcox \& Follett.

May, J. (2008, October 27). Commentary: ATA President/CEO says keep deregulation as is. Aviation Week and Space Technology, 51. 
McCormick, B. (2004). Aerospace engineering education during the first century of flight. Reston, Va.: American Institute of Aeronautics and Astronautics.

McCurry, W. (2000). General aviation after World War II. In T. Brady (Ed.), The American aviation experience: A history. (pp. 241-254). Carbondale, IL: Southern Illinois University Press.

Mingos, H. (1930). The birth of an industry. New York City: W.B. Conkey Co.

National Center for Education Statistics. (2010). Digest of education statistics. Washington D.C.: Institute of Education Sciences.

Saini, A. (2011). An examination of the airmail act of 1925 and the air commerce act of 1926. Unpublished presentation. Embry Riddle Aeronautical University, Daytona Beach, FL.

Shulman, S. (2003). Unlocking the sky: Glenn Hammond Curtiss and the race to invent the airplane. New York City: Harper Collins.

Metropolitan Nashville Airport Authority. (2003). A history of aviation in Nashville, Tennessee and the metropolitan Nashville airport authority: The beginning of the adventure. Nashville, TN: Author.

Tierney, D. (2011, March 15). The F-35: A weapon costs more than Australia. The Atlantic.

Tom, Y. (2009). The perennial crisis of the airline industry: Deregulation and innovation. The Claremont Graduate University, The Claremont Graduate University. ProQuest Dissertations and Theses.

United States Department of the Labor. (2011). Occupational employment statistics. [Data set]. Retrieved from http://www.bls.gov/oes/.

United States. Congress. Senate. Congressional Budget Office. (2006). Immigration policy in the United States. Washington D.C.: U.S. Government Printing Office. Retrieved from http://www.cbo.gov/ftpdocs/70xx/doc7051/02-28-Immigration.pdf

U.S. Department of Commerce. (2011). National economic historical accounts. [Data set]. Retrieved from http://www.bea.gov/iTable/index_industry.cfm.

Whealan George, K. (2011). Aircraft manufacturing during World War I. Unpublished manuscript. Embry Riddle Aeronautical University. Daytona Beach, FL. 
Wilson, B. (2008). Interview with Alfred Kahn - founding father of airline deregulation / architect of deregulation. Aviation Week and Space Technology, 50.

World rivalry in flying machines and motor boats. (1908). Current Literature, 45(September), 239-44. 